\title{
Multilevel analysis of the bacterial diversity along the environmental gradient Río de la Plata-South Atlantic Ocean
}

\author{
Cecilia Alonso ${ }^{1, *}$, Paola Gómez-Pereira ${ }^{2}$, Alban Ramette ${ }^{2}$, Leonardo Ortega ${ }^{3}$, \\ Bernhard M. Fuchs ${ }^{2}$, Rudolf Amann ${ }^{2}$ \\ ${ }^{1}$ Instituto de Investigaciones Biológicas Clemente Estable, Av. Italia 3318, CP 11600, Montevideo, Uruguay \\ ${ }^{2}$ Max Planck Institute for Marine Microbiology, Celsiusstr. 1, 28359 Bremen, Germany \\ ${ }^{3}$ Dirección Nacional de Recursos Acuáticos, Constituyente 1497, CP 11200, Montevideo, Uruguay
}

\begin{abstract}
The Río de la Plata is the world's largest estuary, draining the second largest basin of South America. In spite of its key significance at the local and global scale, this is the first attempt made so far to characterize the bacterial diversity of this system. We employed a suite of molecular methods to analyze the bacterial diversity at different phylogenetic levels, both in terms of richness and evenness, and we related these findings to physicochemical parameters. A clear environmental gradient was observed with 3 distinctive zones (riverine, frontal, and marine). In turn, the bacterial communities appeared highly diverse and strongly structured by the environment. A high number (324) of different operational taxonomic units (OTUs) were identified by automated ribosomal intergenic spacer analysis (ARISA). The ARISA results suggested that the composition of bacterioplankton communities was strongly related to physicochemical water characteristics, and that the bacterioplankton had little overlap with the bacterial assemblage of the sediments. Catalyzed reporter deposition-fluorescence in situ hybridization (CARD-FISH) indicated that Betaproteobacteria and Actinobacteria were more abundant in the riverine zone, whereas Gammaproteobacteria and Planctomycetes preferred the marine waters. The relative abundance of Bacteroidetes peaked in the frontal zone, and Alphaproteobacteria were numerically dominant throughout the estuary. The analysis of about 300 almost full-length 16S rRNA gene sequences pointed to the existence of ubiquitous phylotypes, but also suggested habitat preferences among certain groups. This first look into the bacterial community of the Río de la Plata demonstrated marked diversity patterns, providing further insights into the ecology of globally distributed groups of aquatic bacteria.
\end{abstract}

KEY WORDS: Estuary · Bacteria · Río de la Plata · Diversity · FISH · ARISA · Cloning

\section{INTRODUCTION}

The Río de la Plata estuary, situated between Argentina and Uruguay, covers an area of approximately $38800 \mathrm{~km}^{2}$ and drains the second largest basin of South America. This system entails a highly productive area, sustaining valuable fisheries of Uruguay, Argentina, and international fleets (Bisbal 1995, Martinez \& Retta 2001, Acha et al. 2008). The Río de la Plata also constitutes the main point source of freshwa- ter in the South Atlantic (Boltovskoy et al. 1999). This area is particularly relevant for the global carbon budget, acting as a $\mathrm{CO}_{2}$ sink, especially during spring and summer (Feely et al. 2001, Bianchi et al. 2005).

In spite of its key significance, there is still very limited understanding of basic ecological aspects of the different plankton components of the Río de la Plata, and previous studies have been focused mainly on the phytoplankton assemblage (Carreto et al. 2003, Calliari et al. 2009). The complex dynamic nature of estu- 
arine systems represents a challenge for the study of planktonic communities, but at the same time provides a unique scenario to analyze microbial populations experiencing very different environmental conditions, in a relatively small area.

A number of authors have analyzed the changes in bacterial community composition (BCC) in transitional aquatic environments employing molecular techniques. In their pioneer work Crump et al. (1999) used 16S rRNA gene clone libraries to characterize microbial communities from freshwater and marine portions of the Columbia River estuary. Since then, several researchers have employed fingerprinting methods, predominantly denaturing gradient gel electrophoresis (DGGE), to obtain patterns of BCC in different estuarine systems (e.g. Murray et al. 1996, Hollibaugh et al. 2000, Troussellier et al. 2002, Crump et al. 2004). More recently, Hewson \& Fuhrman (2004) used automated ribosomal intergenic spacer analysis (ARISA) to study the diversity of the microbial communities at Moreton Bay, Australia. Fluorescence in situ hybridization (FISH) has also been employed to determine the abundance of major bacterial groups in a number of estuaries (Bouvier \& del Giorgio 2002, Cottrell \& Kirchman 2003, Zhang et al. 2006).

Although these studies have provided clear insights into the microbial ecology of transitional environments, there is still an obvious need for data on subtropical systems; so far only 2 such systems have been targeted (Hewson \& Fuhrman 2004, Zhang et al. 2006). In addition, there are very few examples of studies in aquatic microbial ecology combining the 3 methodological approaches mentioned above (Anton et al. 2000, Watanabe et al. 2000, Simek et al. 2001, Alonso-Sáez et al. 2007). This strategy is desirable: there is still a need to address variations in $\mathrm{BCC}$ at different phylogenetic levels and to link this information with appropriate environmental parameters, in order to gain deeper understanding of the ecology of aquatic bacteria.

Although a few eco-physiological aspects appear to be well established (e.g. negative correlation of natural abundances of Betaproteobacteria and salinity) (Glöckner et al. 1999, Bouvier \& del Giorgio 2002), there is still considerable lack of information about the factors controlling the distribution of bacterial populations. Even the most recent meta-analysis of $16 \mathrm{~S}$ gene sequences, which disentangled the effect of salinity on BCC into salt composition and salt concentration influence, stressed the lack of contextual data and the strong sampling bias towards northern temperate regions as serious limitations for bio-geographical studies (Barberán \& Casamayor
2010). Furthermore, the major phylogenetic groups encompass members with quite different ecological strategies (Alonso \& Pernthaler 2006, Alonso-Saez \& Gasol 2007), particularly in habitats characterized by sharp environmental transitions (Alonso et al. 2009).

The aim of the present study was to employ a suite of molecular methods to analyze the bacterial diversity along a transect in a subtropical estuary, and to relate diversity and community composition patterns to environmental data.

\section{MATERIALS AND METHODS}

Study area. The Río de la Plata is a large-scale estuary characterized by a salt-wedge regime, a low tidal amplitude $(<1 \mathrm{~m})$, a broad and permanent connection to the sea, and high susceptibility to atmospheric forcing due to its large extension and shallow water depth (Acha et al. 2008 and references therein). The position of the turbidity maximum is highly variable according to tide, river discharge, and wind (Framiñan \& Brown 1996). The resulting outflow is on average $22000 \mathrm{~m}^{3} \mathrm{~s}^{-1}$ (Framiñan \& Brown 1996), showing seasonal variability with maxima in March-June and September-October, and a minimum in December-March (Guerrero et al. 1997, Nagy et al. 2002).

Sampling. The cruise ARTEMISA1 was carried out during late austral summer (March) 2008 onboard RV 'Aldebaran' (DINARA). A transect of 80 nautical miles (ca. $150 \mathrm{~km}$ ) with 9 sampling stations (S3 to S11) was followed along the salinity gradient occurring in the outer region of the Río de la Plata; the distance between stations was 10 nautical miles (Fig. 1). The bottom depth covered a range from a minimum of $5 \mathrm{~m}$ to a maximum of $30 \mathrm{~m}$.

At each station, a CTD cast (SBE-19) profiled the water column from the surface to the bottom. Accord-

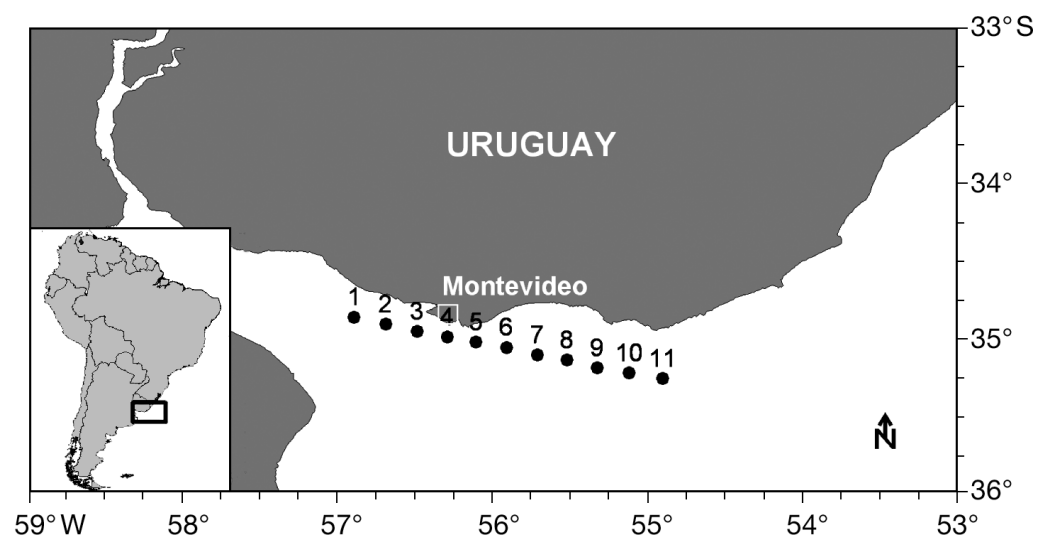

Fig. 1. Transect of the ARTEMISA1 cruise indicating sampling stations (3 to 11 ) 
ing to the CTD data, 6 stations were chosen for sampling bacterial communities. Surface water samples were taken using a bucket; sub-surface water samples were taken with Niskin bottles. All sampling devices were acid-washed and seawater-rinsed prior to use. A Smith-McIntyre bottom grab sampler was used for sampling sediment.

Physicochemical characterization. Water samples were filtered through glass fiber filters (Whatman GF/F, $47 \mathrm{~mm}$ ) to assess total chlorophyll a (chl a) and suspended particulate matter. Filters were stored dried and frozen for subsequent analysis in the laboratory. Chlorophyll was extracted with $90 \%$ acetone and analyzed with a Shimadzu UV-2101 PC, UV-VIS scanning spectrophotometer. Chl a concentration was calculated according to Jeffrey \& Humphrey (1975) with correction for phaeopigments (Lorenzen 1967). Suspended particulate matter was estimated by the gravimetric method of the particulate material (Strickland \& Parsons 1972).

Water samples for dissolved nutrient analysis were filtered through a Whatman GF/C glass fiber filter. Inorganic nutrient concentrations measured at each station included total nitrogen (TN) and total phosphorus (TP) (Valderrama 1981), and dissolved fractions of nitrite (Strickland \& Parsons 1972), nitrate (Eaton et al. 2005), ammonium (Koroleff 1976), and soluble reactive phosphorus (SRP) (Murphy \& Riley 1962). Nutrient concentrations were determined colorimetrically employing a Shimadzu UV-2101 PC, UV-VIS scanning spectrophotometer.

Sample collection for determination of in situ abundance of different bacterial populations. Water samples were fixed with freshly prepared buffered paraformaldehyde solution (PFA) at a final concentration of $1 \%$ for $24 \mathrm{~h}$. Portions of $10 \mathrm{ml}$ were then filtered through polycarbonate filters (type GTTP, $0.2 \mu \mathrm{m}$ pore size, $47 \mathrm{~mm}$ diameter; Millipore). The filters were rinsed twice with sterile phosphate buffered saline (PBS) and stored at $-20^{\circ} \mathrm{C}$ until further analysis.

DNA collection and extraction. Ten liters of the water sample from each station were pre-filtered through $50 \mu \mathrm{m}$ and $10 \mu \mathrm{m}$ and then filtered onto cellulose acetate filters $(142 \mathrm{~mm}$ diameter, $0.2 \mu \mathrm{m}$ pore size; Sartorius). Filters were stored at $-20^{\circ} \mathrm{C}$ until further processing. For sediment samples, the first centimeter layer was collected using a sterile Petri dish, and the DNA extraction was performed from a $10 \mathrm{~g}$ sub-sample. DNA was extracted following the protocol by Zhou et al. (1996).

Genetic fingerprinting of bacterial communities. The standard ARISA protocol by Ramette (2009) was applied. For the amplification of the intergenic spacer the forward universal primer ITSF and the eubacterial ITSReub reverse primer were employed (Cardinale et al. 2004). The reverse primer was labeled with the phosphoramidite dye HEX. PCR conditions, purification, and sample preparation prior to submitting to capillary electrophoresis were done as described previously (Ramette 2009). The electropherograms obtained from fragment analysis were examined with GeneMapper software v. 3.7 (Applied Biosystems). The output tables from GeneMapper were analyzed using custom R binning scripts (Ramette 2009). Triplicates samples were analyzed for replicated fragments. Further analysis was based on the fragments that appeared in at least 2 of the replicates, generating an average profile for each sample.

Cluster analysis was performed using relative fluorescence intensity (RFI) data. The similarity matrix between samples was calculated with the Bray-Curtis coefficient and the group average was used as the linkage algorithm. Significance of the grouping in the cluster analysis was tested using similarity profile permutation test (SIMPROF) at 99\% significance level. SIMPROF tests for statistically significant evidence of genuine clusters in an a priori unstructured set of samples (Clarke et al. 2008). Analysis was performed with the software Primer v. 6 (version 6.1.5, Primer-E) (Clarke \& Gorley 2006).

Construction of clone libraries. Almost complete bacterial 16S rRNA genes were amplified via PCR using the primers 27f-YM (Frank et al. 2008) and 1492GM4R (Muyzer et al. 1995). PCR products were purified using the QIAquick PCR purification kit (Qiagen) and cloned using the pGEM ${ }^{\circledR}$-T easy system (Invitrogen). Competent Escherichia coli cells (house-made) were transformed and plated on Luria-Bertani (LB) agar plates containing $50 \mu \mathrm{g} \mathrm{ml}^{-1}$ of ampicillin. Single colonies were transferred into microtiter plates (MTP) containing ampicillin-amended LB medium (50 $\mu \mathrm{g}$ $\left.\mathrm{ml}^{-1}\right)$ and cultivated overnight at $37^{\circ} \mathrm{C}$. Glycerol $(12 \%$ final concentration) was added to each well, and the MTPs were stored at $-20^{\circ} \mathrm{C}$ until further processing.

Sequencing. Plasmids were isolated from clones with Montage plasmid MiniPrep96 kit (Millipore), and 50 to $100 \mathrm{ng}$ of template was used per sequencing reaction. Sequencing reactions were performed using ABI BigDye ${ }^{\circledR}$ chemistry and an ABI 3100 genetic analyzer (Applied Biosystems) according to the manufacturer's instructions. M13F and M13R primers were used to obtain 298 gene sequences of $16 \mathrm{~S}$ rRNA. Partial sequences were assembled and manually corrected using the software Sequencher (Gene Codes). Chimeric sequences were identified using the Mallard and Pintail programs (Ashelford et al. 2006) and 5 sequences were thus removed. The 16S rRNA gene sequences produced during the present study were deposited in GenBank under accession numbers GU230187 to GU230468. 
Phylogenetic reconstructions. Phylogenetic analyses were performed using the ARB software package (Ludwig et al. 2004). The sequences were automatically pre-aligned using the SILVA tool Aligner (www.arb-silva.de) (Pruesse et al. 2007). Alignments were subsequently improved manually considering the secondary structure of the rRNA molecule. Tree reconstruction was done with the maximum likelihood algorithm RaxML (Stamatakis 2006) on various subsets of the complete data set.

Population analysis by CARD-FISH. The percentages of different microbial taxa in the water samples were determined by FISH with horseradish peroxidaselabeled oligonucleotide probes and catalyzed reporter deposition (CARD-FISH) (Pernthaler et al. 2002). The following probes were used to characterize the microbial community: EUB338 I-III (most Bacteria) (Daims et al. 1999), ALF968 (most Alphaproteobacteria) (Neef 1997), BET42a (most Betaproteobacteria) (Manz et al. 1992), GAM42a (most Gammaproteobacteria) (Manz et al. 1992), CF319a (many groups of Bacteroidetes) (Manz et al. 1996), HGC69a (most Actinobacteria) (Roller et al. 1994), PLA46 most Planctomycetes (Neef et al. 1998), SAR11-441 (members of the alphaproteobacterial SAR11 clade) (Morris et al. 2002), ROS537 (members of the alphaproteobacterial RoseobacterSulfitobacter-Silicibacter clade) (Eilers et al. 2001), NOR5-730 (members of the gammaproteobacterial NOR5/OM60 clade) (Eilers et al. 2001), SAR86-1245 (members of the gammaproteobacterial SAR86 clade) (Eilers et al. 2000), POL740 (members of the genus Polaribacter of Bacteroidetes) (Malmstrom et al. 2007), CF6-1267 (members of DE cluster 2 of the Flavobacteria class of the phylum Bacteroidetes) (Kirchman et al. 2003), and VIS1-575 (uncultured marine VIS1 clade of the Flavobacteria class of the phylum Bacteroidetes) (Gomez-Pereira et al. 2010).

All probes were purchased from Biomers.net. Signal amplification was performed with fluorescein isothiocyanate (FITC)-labeled tyramides (Molecular Probes). CARD-FISH preparations were counterstained with DAPI at a final concentration of $1 \mu \mathrm{g} \mathrm{ml}^{-1}$. DAPI- and CARD-FISH-stained cells were counted manually, achieving a minimum of 1000 cells $^{\text {filter }}{ }^{-1}$.

Statistical analyses. ARISA profiles and CARD-FISH abundance data sets were Hellinger-transformed prior to applying linear multivariate methods (Legendre \& Gallagher 2001, Ramette 2007). To relate variation in microbial data to variation in spatial and environmental parameters, redundancy analyses (RDA) were performed on quantitative variables that were standardized to unit variance and zero mean. Spatial coordinates (latitude and longitude) were converted to Cartesian spatial coordinates $(x, y)$ using the R package gmt. A forward selection procedure was per- formed to retain only the environmental variables that significantly explained variation in bacterial data (Legendre \& Legendre 1998). Following this procedure, the selected terms were then analyzed in concert with the other contextual parameters using the R package vegan (http://cc.oulu.fi/ jarioksa/softhelp/vegan. $h t m l)$.

\section{RESULTS}

The vertical distribution of temperature (Fig. 2A) showed a seaward decrease (i.e. from Stns S3 to S11). The highest temperatures, concomitant with a low thermal stratification, were detected from Stns S3 to S7 (24.5 to $22.5^{\circ} \mathrm{C}$, respectively). At Stns S8 to S11, lower temperatures and higher stratification were found $\left(22^{\circ} \mathrm{C}\right.$ at the surface and $17^{\circ} \mathrm{C}$ at the bottom of Stn S11). The vertical distribution of salinity (Fig. 2B) presented a steep seaward gradient. The lower salinity values (3) were observed at the riverine Stn S3. The frontal zone involved Stns S4, S5, and S6, where the steepest salinity gradient was observed, as surface salinity increased sharply from 3 to 29 at Stns S3 to S6. From Stn S7 on, a practically homogeneous marine water column was found.

The surface concentration of suspended particulate matter showed a clear decline towards the Atlantic Ocean, with Stn S3 exhibiting the highest concentration (5.4 $\mathrm{mg} \mathrm{l}^{-1}$ ) (Fig. 2C). Organic matter, chl $a$, and phaeopigments increased sharply from Stn S3 to a maximum at Stn S5, and then decreased with the oceanic influence (Fig. 2C). Chl a concentration ranged from $0.03 \mu \mathrm{g} \mathrm{l}^{-1}$ at Stn S9 to $6.4 \mu \mathrm{g} \mathrm{l}^{-1}$ at Stn S5 (Fig. 2C).

In general, higher concentrations of most nutrients were found in the riverine part (TN, TP, SRP, and nitrate). Nutrient levels decreased towards the marine stations, e.g. TN decreased from 290 to $130 \mathrm{\mu g} \mathrm{l}^{-1}$, and TP from 94 to $38 \mathrm{\mu g} \mathrm{l}^{-1}$ (Fig. 2D). Nevertheless, a local peak of nutrients was found at Stn S5 at a depth of $8 \mathrm{~m}$, where the concentrations of TN and TP were the highest found along the transect, 293 and $151 \mu \mathrm{g} \mathrm{l}^{-1}$, respectively. Ammonium was undetectable along the whole transect, with the exception of the surface water at Stn S9, where ammonium concentration was $9 \mu_{\text {g }} \mathrm{l}^{-1}$ (Fig. 2D).

\section{Bacterial diversity patterns along the environmental gradient}

A total of 324 different operational taxonomic units (OTUs) were identified by ARISA (Fig. 3A). The highest number of amplicons (124) was found in the riverine surface water (Stn S3) (Fig. 3B). In contrast, the 

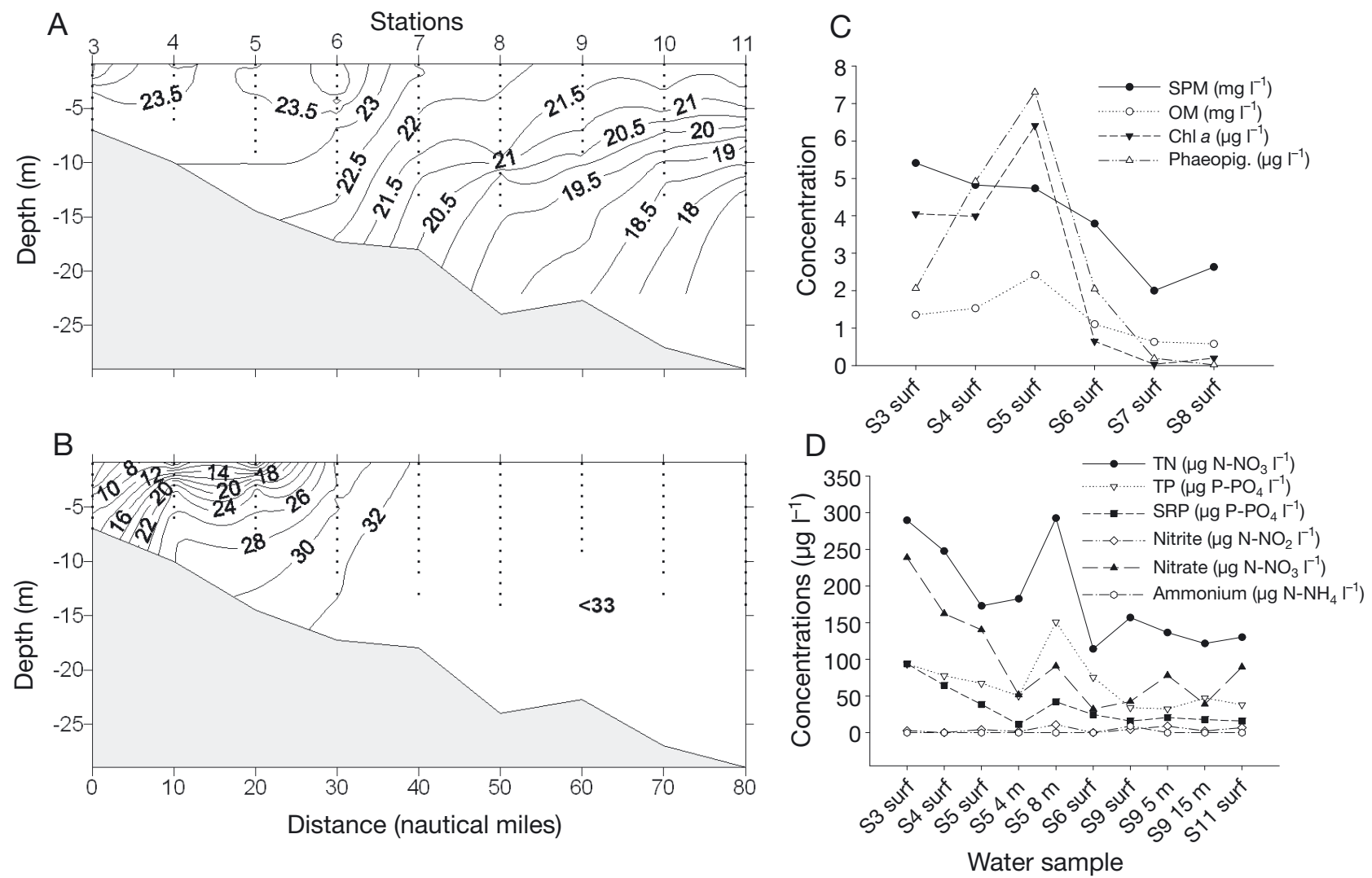

Fig. 2. Distribution of (A) temperature, (B) salinity, (C) suspended particulate matter (SPM), organic matter (OM), chlorophyll a $(\mathrm{Chl} a$ ), and pheopigments (Phaeopig.), and (D) total nitrogen (TN), total phosphorus (TP), nitrite, nitrate, ammonium, and soluble reactive phosphorus (SRP) along the sampling transect. $\mathrm{S} 3=\mathrm{Stn} 3, \mathrm{~S} 5=\mathrm{Stn} 5$, etc.; $4 \mathrm{~m}=4 \mathrm{~m}$ depth, $5 \mathrm{~m}=5 \mathrm{~m}$ depth, etc.
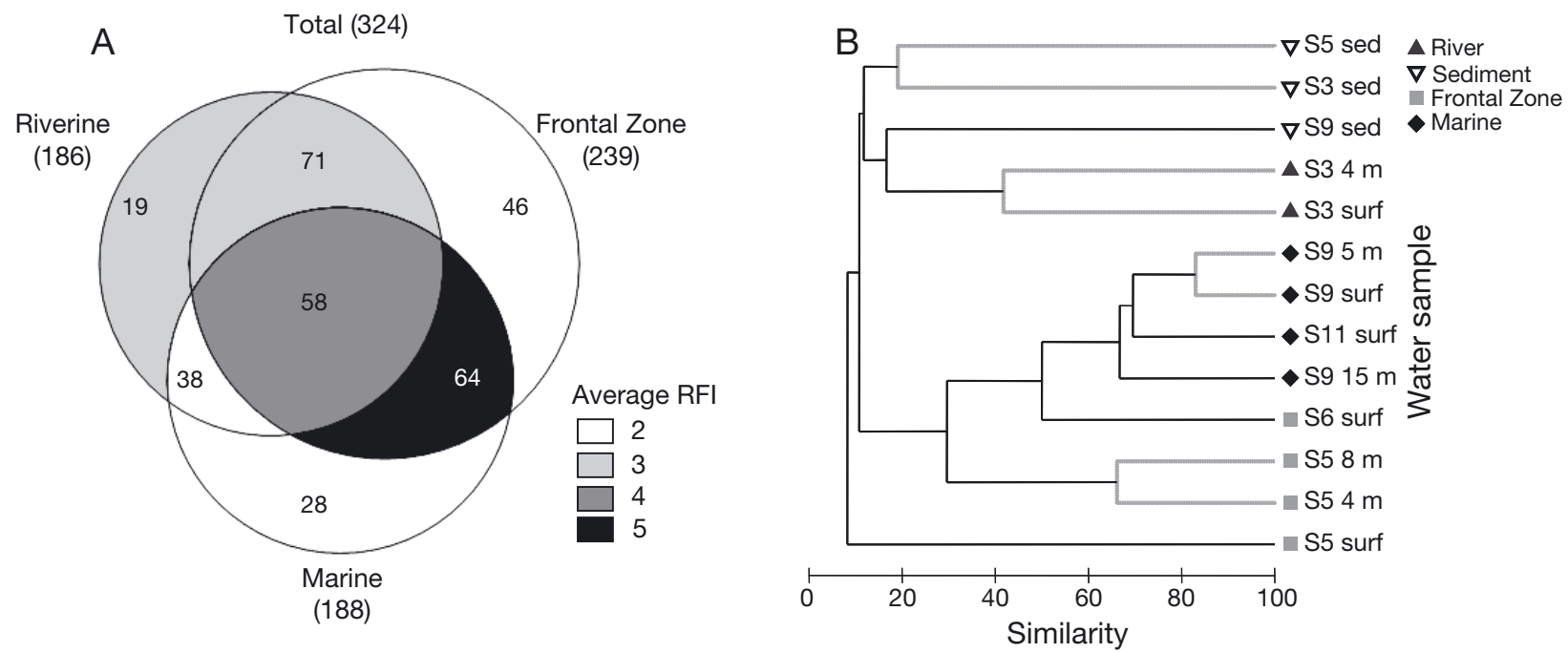

Fig. 3. (A) Distribution of automated ribosomal intergenic spacer analysis (ARISA) amplicons among samples. Numbers inside the diagram indicate the number of amplicons corresponding to each kind of sample set. Numbers in parentheses indicate the total number of amplicons recovered in the riverine, frontal zone, or marine samples. Colors represent a sample classification based on the average values of relative fluorescence intensity (RFI) of the amplicons contained in a given sample set. (B) Sample clustering based on ARISA data. Cluster analysis was performed using the group average based on RFI values using the Bray-Curtis similarity index. Black lines in the dendrogram represent significant clusters at the $99 \%$ level using SIMPROF test; grey lines represent non-significant clusters at this level. See Fig. 2 for water sample details 
lowest number of amplicons (54) occurred in the sediment sample of the same station (Fig. 3B). Around 50\% of the obtained OTUs were present in 2 of the 3 zones of the gradient (riverine, frontal, and marine), whereas 58 OTUs were present in all 3 zones (Fig. 3A). The highest number of OTUs (239) was retrieved from the frontal zone stations; most of these amplicons were also obtained either from the riverine and/or the marine samples (Fig. 3A). Several OTUs were distinct to habitats: the number of unique OTUs per habitat was 19 (riverine), 46 (frontal zone), and 28 (marine) (Fig. 3A). The OTU with the highest RFI value in the frontal zone (an amplicon of a length of approximately $300 \mathrm{bp}$ ) was also present in the marine zone (data not shown). In the marine and riverine samples, fragments with highest RFIs had amplicon lengths of 334 and $218 \mathrm{bp}$, respectively, and none of them was habitatexclusive (data not shown).

Although each sample displayed a unique community fingerprint, a series of diversity patterns was revealed, both in the longitudinal and in the depth dimensions. The sediment samples were more similar to each other than to the water samples of the corresponding stations (Fig. 3B). The sediment communities appeared relatively similar to the water column assemblage from the riverine Stn S3 (Fig. 3B). Although water samples from the surface and $4 \mathrm{~m}$ depth of Stn S3 clustered together, they exhibited lower similarity indexes than comparable samples taken at the marine stations (Fig. 3B). All water samples from fully marine stations (S9 to S11) clustered closely together, and depth was not a decisive factor for the clustering (Fig. 3B). For example, the water sample from Stn S9 taken at $15 \mathrm{~m}$ depth had a similarity Bray-Curtis index of 0.74 with the surface water from Stn S11 (Fig. 3B). The marine stations shared more OTUs between them, at any depth, than with any other sample (Fig. 3B). In contrast, in the frontal zone samples clustered according to depth rather than to station, i.e. water samples from Stn S5 at 4 and $8 \mathrm{~m}$ depth were more closely related to the marine samples than with the surface water at the same station (Fig. 3B). Interestingly, the surface sample of the center of the frontal zone was clearly distinct from all other samples (Fig. 3B).

\section{BCC as revealed by FISH and clone libraries}

Average cell detection with the EUB338 I-III probe was $77.8 \%(\mathrm{SD}=8.7 \% ; \mathrm{n}=11)$ of all DAPI-stained objects. Bacterial abundance was higher in the riverine and frontal zones compared to the marine portion of the transect (Fig. 4). The sum of counts with the probes targeting the main bacterial groups (Alphaproteobacteria, Betaproteobacteria, Gammaproteo- bacteria, Bacteroidetes, Actinobacteria, and Planctomycetes) generally accounted for virtually all bacterial cells (Fig. 4).

Alphaproteobacteria dominated the community in all water samples, representing between 36 and $57 \%$ of all bacterial cells (Fig. 4). Accordingly, most of the sequences retrieved from the water column libraries belonged to members of this group (Fig. 5). Virtually all Alphaproteobacteria cells in the Río de la Plata estuary could be assigned to either the SAR11 or the Roseobacter clades by probes SAR11-441 and ROS537, respectively (Fig. 4).

Most of the alphaproteobacterial sequences retrieved were affiliated to SAR11 (Fig. 5A), and the majority of them were targeted by the SAR11-441 probe. All Roseobacter-related sequences recovered in the 3 surface water libraries were targeted by probe ROS537. Beside these 2 main alphaproteobacterial clades, a few sequences related to the order Rickettsiales were also retrieved from the water column and the sediment (Fig. 5A).

Identical SAR11 16S rRNA gene sequences were recovered in all 3 surface water libraries (e.g. 17 sequences represented by GU230214 from the marine station, GU230205 from the riverine station, and GU230204 from the frontal zone) (Fig. 5A). Other sequence types were only present in the riverine and frontal zone (e.g. 12 sequences represented by GU230226 and GU230225) (Fig. 5A). Finally, clusters of SAR11-related sequences were exclusively recovered from the marine library (e.g. 12 sequences represented by GU230240) (Fig. 5A). The sequences affiliated to Roseobacter were few, but a phylotype differentiation between the riverine/frontal zone (GU-230200/230284) and the marine sample (GU230201; GU230194) was apparent (Fig. 5A).

Bacteroidetes was the second most abundant group. Cells hybridizing with probe CF319a constituted on average $23 \%$ of all bacteria (Fig. 4). Members of this group were particularly abundant at Stns S4 and S5 (Fig. 4). In the very center of the frontal zone (Stn S5), Bacteroidetes accounted for about one third of all bacteria. Their abundance decreased towards the marine and the riverine stations (Fig. 4).

The specific probes POL740, CF6-1267, and VIS1575, targeting different groups of Flavobacteria, accounted on average for one third of the cells targeted by CF319a (Fig.4). Among them, Polaribacter spp. cells targeted by POL740 were the most abundant ones, particularly in the riverine and frontal zones, and their abundance decreased with depth (Fig. 4). Abundance of the flavobacterial clade targeted by VIS1-575 was higher in the frontal and marine zones, and for a given station increased with depth (Fig. 4). CF6-1267targeted cells were the least abundant of the Bacteroidetes targeted groups and reached their maximum in the frontal zone (Fig. 4). 

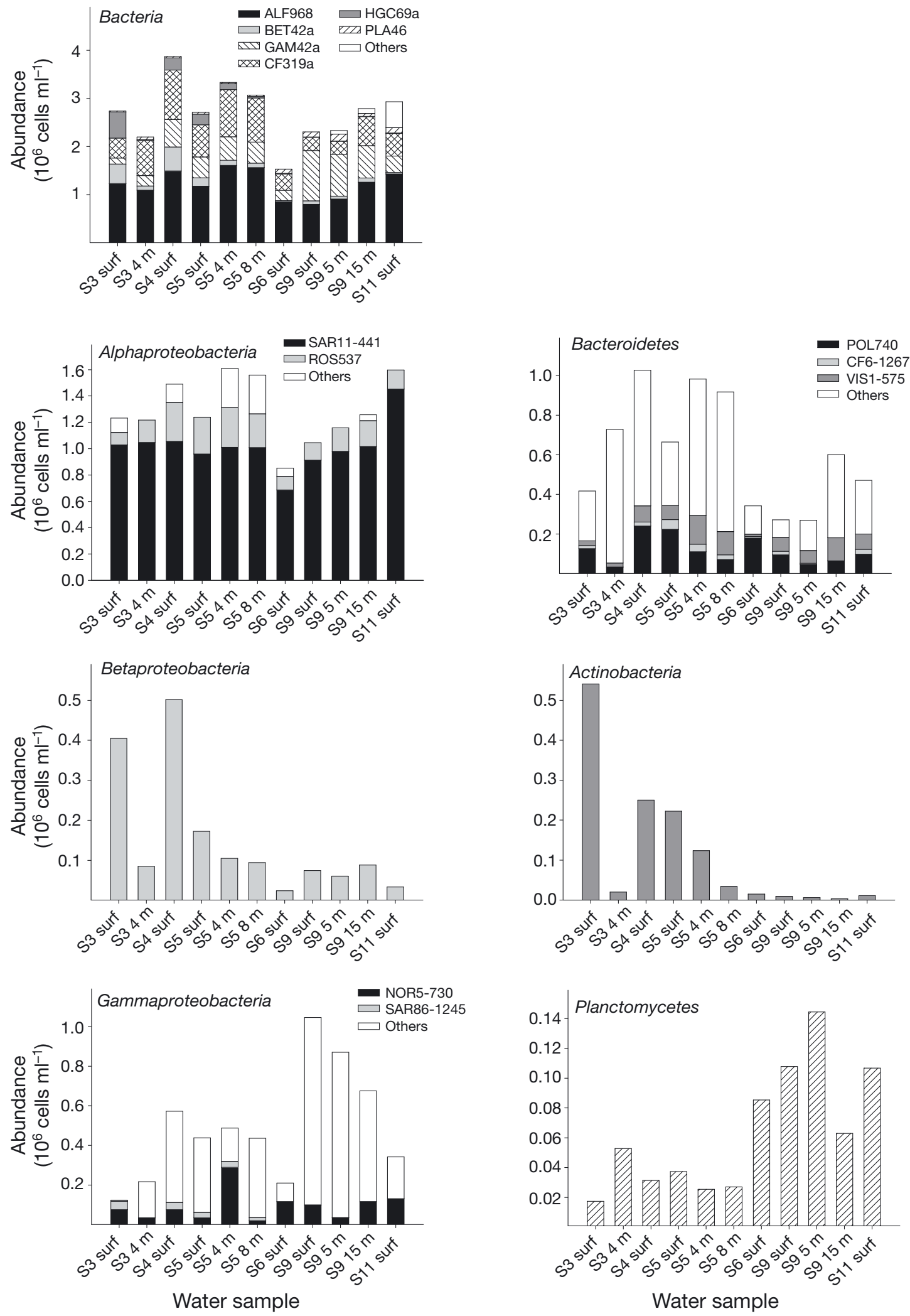

Fig. 4. Abundance of the main bacterial groups as determined by catalyzed reporter deposition-fluorescence in situ hybridization (CARD-FISH). 'Others' indicates the difference in counts between the sum of the specific probes and the general probe used to target a given bacterial clade. The target of each probe is detailed in 'Materials and Methods'. See Fig. 2 for water sample details 
A

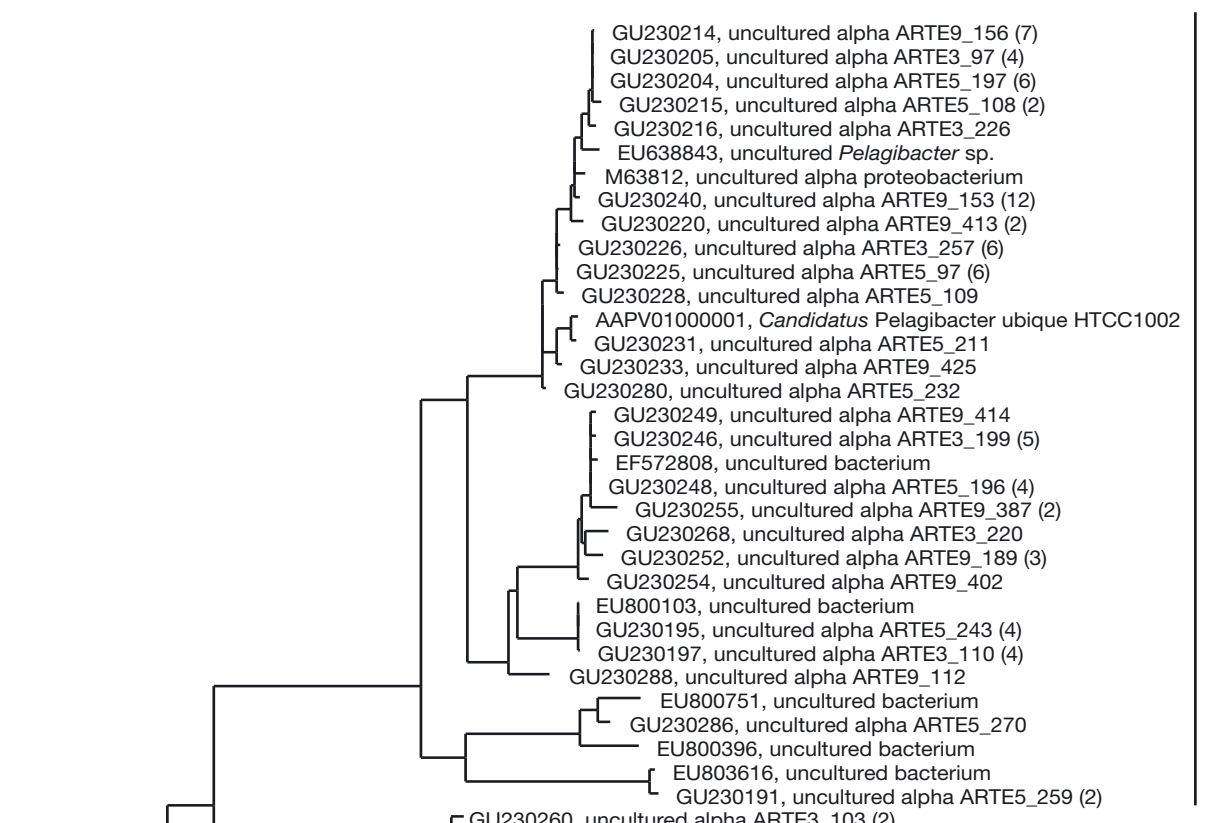

SAR11

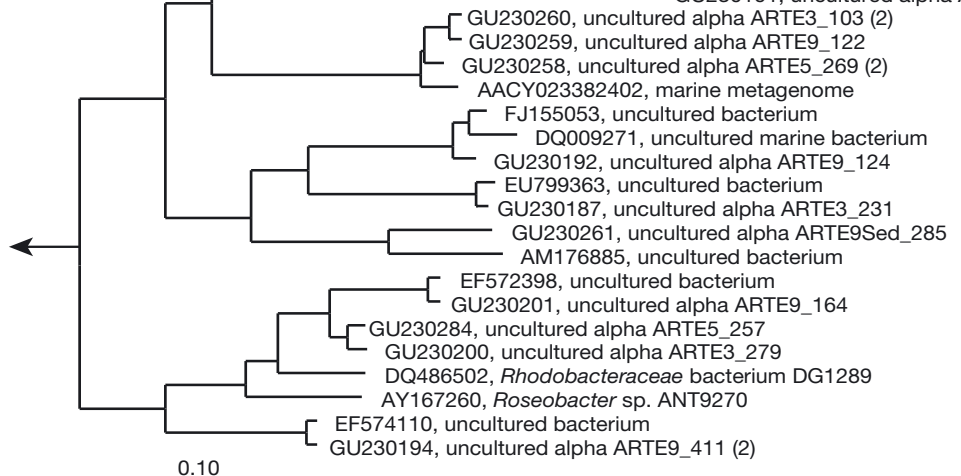

Roseobacter

B

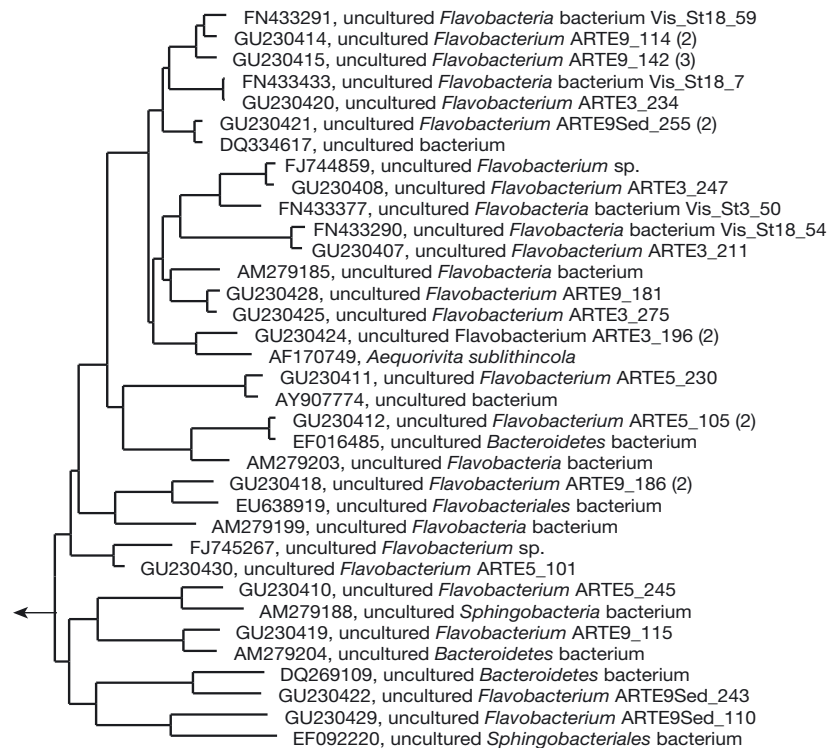

VIS3

VIS2

NS9

NS6

Sphingobacteria

0.10

Fig. 5. Phylogenetic relationships of 16S rRNA gene sequences from Río de la Plata bacterioplankton for (A) Alphaproteobacteria, (B) Bacteroidetes, and (C) Gammaproteobacteria. GenBank accession numbers are given for 1 representative per unique sequence type. Numbers in parenthesis indicate the number of identical sequences retrieved per phylotype. Clones are named according to their origin: riverine (ARTE3), frontal zone (ARTE5), marine water surface (ARTE9), and marine sediment

(ARTE9Sed). Horizontal bar below each tree: $10 \%$ of estimated sequence divergence 
C

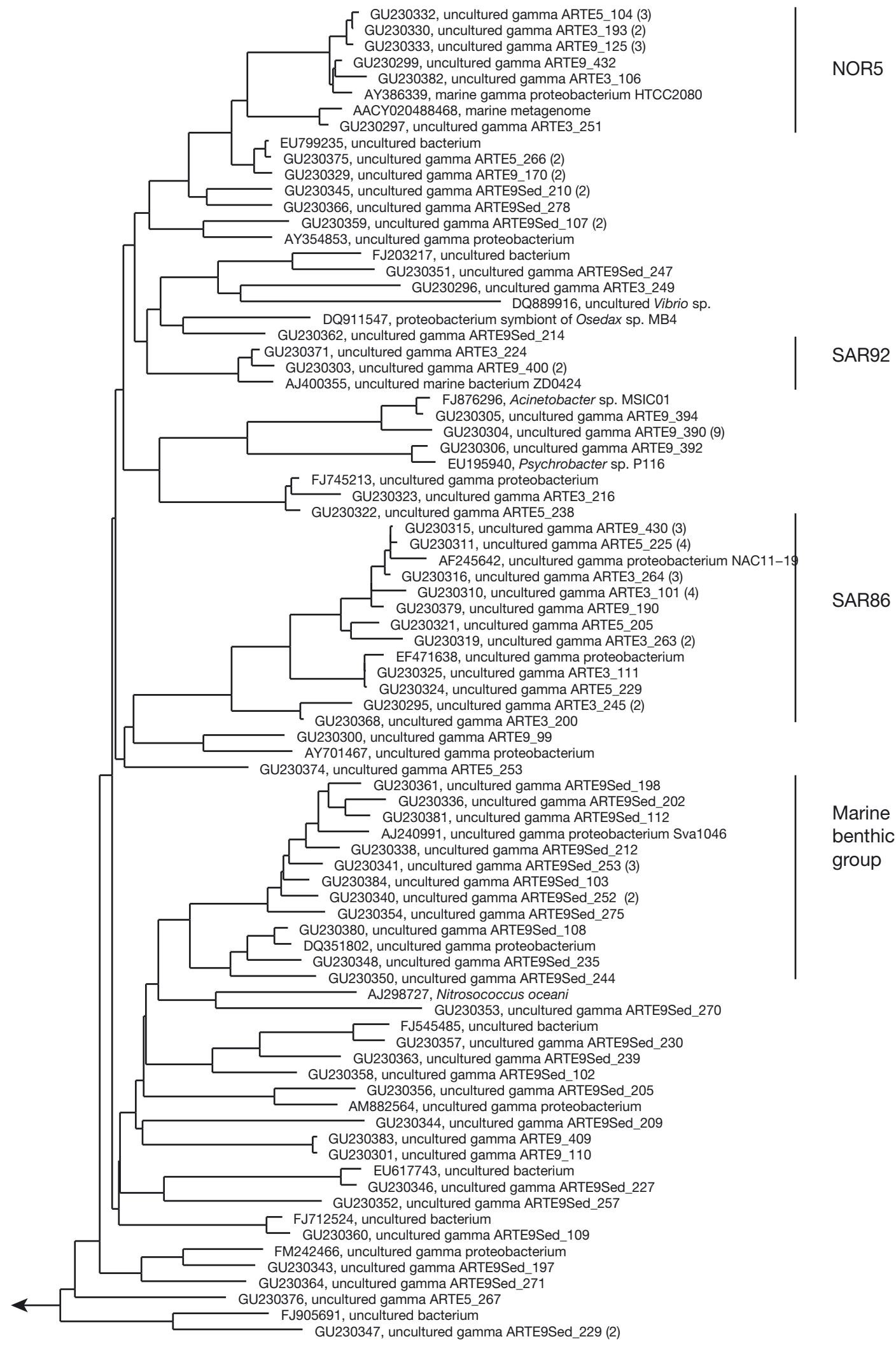


The majority of sequences retrieved from all stations were affiliated to the class Flavobacteria; in addition, members of Sphingobacteria were also identified (Fig. 5B). All Bacteroidetes sequences retrieved were characteristic of the different samples; none of them was shared between libraries. Several of the sequences obtained belonged to clusters previously defined with phylotypes recovered from other coastal (North Sea) or open-ocean (mid-Atlantic) sites (Fig. 5B). None of the recovered sequences was targeted by any of the specific probes used (POL740, CF6-1267, and VIS1-575).

Gammaproteobacteria were generally the third group in abundance. On average, they were $19 \%$ of all bacterial cells, with the exception of Stn S9 where, depending on the depth, they constituted 24 to $47 \%$ of all cells (Fig.4).

Hybridizations with the probe SAR86-1245 showed that members of SAR86 clade constituted on average $6 \%$ of Gammaproteobacteria (Fig. 4). Other ubiquitous members of this class were members of the OM60/ NOR5 clade as detected by probe NOR5-730. They represented on average $26 \%$ of Gammaproteobacteria, being particularly abundant at Stn S5 at $4 \mathrm{~m}$ depth, and at the surface of Stn S6 (Fig. 4).

Sequences targeted by the NOR5-730 and SAR861245 probes were retrieved from all libraries. Gammaproteobacterial sequences accounted for about one third of all sequences obtained. Most of the sequences derived from the water column were affiliated to Oceanospirillales and Alteromonadales (Fig. 5C). Some of them were shared by all 3 surface-water libraries, e.g. the OM60/NOR5-related cluster represented by the phylotypes GU230332, GU230330, and GU230333. Also, sequences related to the SAR86 clade were shared between all surface-water libraries (e.g. cluster represented by GU230311, GU230315, and GU230316) (Fig. 5C). Yet, sequences from both groups were recovered exclusively from either the river frontal zone or marine libraries (e.g. SAR86-related members represented by GU230310 recovered from the riverine library).

The analysis of the sequences retrieved from the clone library at Stn S9 did not give strong hints about the identity of the main contributors to the disproportionate gammaproteobacterial abundance at this station. Various gammaproteobacterial sequences related to OM60/NOR5, Oceanospirillales, Alteromonadales, and the genera Acinetobacter and Psychrobacter were exclusively found in the surface water of marine Stn S9 (Fig. 5C). However, hybridizations with available probes targeting several groups of marine Gammaproteobacteria (some of them previously reported to bloom in marine or coastal lagoon samples: Acinetobacter spp., Alteromonas spp., Pseudoalteromonas spp., Oceanospirillum spp., Stenotrophomonas maltophilia, and Vibrio spp.) did not yield any positive result (data not shown).

Gammaproteobacterial sequences found in the sediment of Stn S9 were very diverse and always closely related to sequences retrieved from sediment samples from a variety of systems (e.g. Wadden Sea, Yellow Sea, mid-Atlantic ridge) (Fig. 5C). Several of them were affiliated to the marine benthic group, while none of them was shared with the water column (Fig. 5C).

Betaproteobacteria were minor components of the community $(<5 \%$ of all bacteria), except for the surface-water samples at the stations with lower salinity, where they accounted for 16 and $14 \%$ at Stns S3 and S4, respectively (Fig. 4). Only 1 betaproteobacterial sequence was retrieved, in the clone library from the frontal zone, which affiliated with the genus Methylophilus (data not shown).

Actinobacteria were highly abundant at low-salinity sites (up to $>20 \%$ of all bacteria in the surface water of Stn S3) and showed a very sharp decrease towards marine stations, where they represented around $1 \%$ of all bacteria (Fig. 4)

Only a few actinobacterial sequences were retrieved from the water samples of the riverine and frontal zone stations and from the marine sediment samples. Most of these sequences affiliated with uncultured Acidimicrobiaceae and Microbacteriaceae previously found in estuarine and marine habitats (Fig. S1A in the supplement at www.int-res.com/articles/suppl/ a061p057_supp.pdf). The phylotypes retrieved from the sediment and the water column formed clearly separated clusters (Fig. S1A). Within the water column samples, 2 groups of sequences were identified, one containing phylotypes derived from the riverine sample, and a second one that included sequences from the riverine and from the frontal zone samples (Fig. S1A).

Planctomycetes were more abundant (up to 6\%) at the marine stations (Fig. 4). In the clone libraries, they were represented by only 3 sequences retrieved from the marine sediment sample; they were closely related to sequences from uncultured Planctomycetes obtained from marine sediments or soil (data not shown).

In marked contrast with the marine water samples, the marine sediment was characterized by the virtual absence of Alphaproteobacteria and the dominant retrieval of gammaproteobacterial and deltaproteobacterial sequences (Fig. 5C; Fig. S1B). Deltaproteobacterial sequences obtained from the marine sediment were affiliated to Desulfobulbaceae and Desulfobacteraceae, and to Haliangiaceae. They were related to uncultured clades previously found in aquatic sediments (Fig. S1B). 
Sequences affiliated to Acidobacteria were exclusively recovered from the marine sediment sample (Fig. S1C). All of them were closely related to sequences from uncultured organisms recovered from marine sediments (Fig. S1C).

\section{DISCUSSION}

Our methodological approach allowed for the recovery of complementary information on the bacterial diversity in the gradient Río de la Plata-South Atlantic Ocean. ARISA yielded an overview of the bacterial diversity at the different sites, guiding the construction of clone libraries. These clone libraries, together with the FISH evaluation, gave hints on the identity and abundance of the individual groups responsible for the global pattern of bacterial diversity in this environment. Altogether, the 3 techniques provided a multilevel view on bacterial biodiversity ranging from phyla (FISH) to species (ARISA, sequencing).

\section{Water and sediment host separate bacterial communities}

The degree of similarity between the sediment samples and the water samples taken at the same stations were very low for all 3 habitats, as indicated by the Bray-Curtis similarity index (Fig. 3B). This pattern, initially derived from the ARISA results, was further confirmed by comparing the sequences retrieved at the marine Stn S9 from the surface water and the sediment (Fig. 5; Fig. S1). Altogether, our findings suggest that despite the shallowness of this system, there is a marked niche specialization of the bacterial groups inhabiting the sediment and the water column, in agreement with an earlier cross-systems analysis (Lozupone \& Knight 2007). However, it should be taken into account that the water samples in the present study were pre-filtered through a $10 \mu \mathrm{m}$ filter previous to DNA extraction, thus the microbial components attached to larger particles were not considered. A specific analysis of the particle-attached bacteria could potentially yield a different result with respect to the diversity sharing between sediment and water. This could be especially expected in the riverine shallower areas, where a rela- tive similarity of the water samples and the sediments was found (Fig. 3B).

\section{Environmental structuring of bacterioplankton communities}

The bacterial community appeared strongly structured by the habitat characteristics on all levels of diversity targeted in the present study. More specifically, the statistical analysis revealed that the BCC in the water column was strongly related to environmental characteristics (Table 1). The geographical factors appeared significant only for ARISA results, indicating that the influence of geography over diversity could be evidenced only at the lower phylogenetic levels (species/strains) (Table 1). Among the environmental parameters, salinity and temperature were the main components explaining the general observed patterns in the bacterial diversity for both ARISA and CARD-FISH results (Table 1), in agreement with the pioneer work from Glöckner et al. (1999), and more recent metaanalysis of 16S sequences (Lozupone \& Knight 2007, Barberán \& Casamayor 2010).

\section{Factors influencing bacterial groups abundance}

Actinobacteria and Betaproteobacteria followed a similar pattern in abundance (Fig. 4; Fig. S2 at www. int-res.com/articles/suppl/a061p057_supp.pdf), suggesting that these groups are affected by similar environmental factors. Their highest numbers were found

Table 1. Effects of environment (ENV: salinity and temperature) and space (2D: longitude and latitude, or 3D: longitude, latitude, and water depth) on bacterial community structure and abundance. Redundancy analysis was applied to Hellinger-transformed automated ribosomal intergenic spacer analysis (ARISA) community data or to catalyzed reporter deposition-fluorescence in situ hybridization (CARD-FISH)-based bacterial abundance under simple constrained models or partial models (i.e. by removing the effects of certain factors whose effects have to be accounted for). Significance was assessed using 1000 permutations of the model residuals at $\mathrm{p}<0.05$. $^{*} \mathrm{p} \leq 0.05,{ }^{* *} \mathrm{p} \leq 0.01$, ${ }^{* * *} \mathrm{p} \leq 0.001, \mathrm{~ns}=$ not significant $(\mathrm{p}>0.05)$

\begin{tabular}{|lccccc|}
\hline \multirow{2}{*}{ Factors } & \multicolumn{3}{c}{ ARISA } & & \multicolumn{2}{c|}{ CARD-FISH -} \\
\cline { 2 - 3 } \cline { 5 - 6 } & F-ratio & $\mathrm{p}$ & & F-ratio & $\mathrm{p}$ \\
\hline ENV + Space 2D & 3.93 & $0.020^{*}$ & & 4.40 & $0.004^{* *}$ \\
ENV + Space 3D & 3.31 & $0.008^{* *}$ & & 4.83 & $0.005^{* *}$ \\
ENV & 3.77 & $0.002^{* *}$ & & 7.97 & $0.001^{* *}$ \\
Space 3D & 1.84 & $0.041^{*}$ & & 2.87 & $0.030^{*}$ \\
Space 2D & 2.33 & $0.020^{*}$ & & 3.56 & $0.012^{*}$ \\
ENV removing space 3D & 3.14 & $0.020^{*}$ & & 4.09 & $0.012^{*}$ \\
ENV removing space 2D & 3.55 & $0.001^{* * *}$ & 3.24 & $0.014^{*}$ \\
Space 3D removing ENV & 1.88 & $0.078(\mathrm{~ns})$ & 1.58 & $0.178(\mathrm{~ns})$ \\
Space 2D removing ENV & 2.36 & $0.020^{*}$ & & 1.41 & $0.289(\mathrm{~ns})$ \\
\hline
\end{tabular}


in samples with lower salinity and higher nutrients values (Fig. 4), and both groups were clearly negatively influenced by increasing salinity (Fig. S2). Actinobacteria and Betaproteobacteria have been shown to display their highest abundances in a variety of freshwater environments (Glöckner et al. 1999, Hahn et al. 2005, Warnecke et al. 2005, Alonso et al. 2009), or in the freshwater parts of transitional environments, like estuaries (Bouvier \& del Giorgio 2002, Kirchman et al. 2005, Zhang et al. 2006), and coastal lagoons (Piccini et al. 2006). Although there are indications that salinity might not be the sole factor explaining their distribution in estuaries (Kirchman et al. 2005), in the present study none of the other factors analyzed was significantly related to their abundance.

The numbers of Gammaproteobacteria appeared negatively correlated to temperature (Fig. S2 in the supplement). As temperature is an indicator of different water masses, we speculate that the observed relationship was an indirect one, actually due to other not yet identified environmental factors. Strikingly, gammaproteobacterial abundance exhibited a pronounced peak at Stn S9, dominating the bacterial community at the water surface (Fig. 4). Previous studies also reported local peaks in gammaproteobacterial abundance in estuarine environments (Bouvier \& del Giorgio 2002, Cottrell \& Kirchman 2003, Zhang et al. 2006). Such high abundances of Gammaproteobacteria, as found in our marine Stn S9, have been previously reported for coastal environments like the Mediterranean Sea (Alonso-Sáez et al. 2007) and the Lagoon of Venice (Simonato et al. 2010), and also in the North Atlantic ocean (Schattenhofer et al. 2009). Bouvier \& del Giorgio (2002) associated local spikes of gammaproteobacterial abundances at the Choptank estuary to point sources of nutrients probably derived from wastewater treatment facilities. In the present study, this peak in gammaproteobacterial abundance coincided with a pronounced peak in ammonium concentration (Fig. 2D). This co-occurrence might indicate a high gammaproteobacterial proteolytic activity during our sampling time at Stn S9 (Woebken et al. 2007).

Certain bacterial groups were particularly abundant at the center of the frontal zone (Stn S5) characterized by peaks in organic matter and chl $a$, and general availability of nutrients, indicating that these taxa would be particularly favored by intermediate salinity and high productivity. These groups included notably members of the flavobacterial groups targeted by the probes POL740, CF6-1267, and VIS1-575, and also the alphaproteobacterial cells targeted by the probe ROS537 (Fig. 4).

Especially high abundances of Bacteroidetes at the turbidity maximum of estuarine systems have been previously reported (Bouvier \& del Giorgio 2002) and increased cell numbers and sequence retrieval of Flavobacteria have been related to high values of chl a and nutrients (Abell \& Bowman 2005b, Pommier et al. 2007). Moreover, members of this group have been repeatedly reported as prone to particle attachment (DeLong et al. 1993, Crump et al. 1999), and as primary colonizers of marine phytoplankton detritus (Pinhassi et al. 2004, Abell \& Bowman 2005a). In addition, they have been frequently found in association to natural and induced phytoplankton blooms (Simon et al. 1999, Riemann et al. 2000, O'Sullivan et al. 2004, Fandino et al. 2005, Grossart et al. 2005). In particular, members of the 3 flavobacterial groups targeted in the present study (Polaribacter spp., DE2 cluster, VIS1 cluster) have been previously observed to be especially abundant in the phycosphere of marine phytoplankton (Gomez-Pereira et al. 2010). Our findings thus provide further support for a potential link between these flavobacterial groups and phytoplankton cells.

The other particularly abundant population in the frontal zone, the Roseobacter cells, have been frequently found in marine coastal and open waters (Moran et al. 2003, Pinhassi \& Berman 2003, Alonso \& Pernthaler 2006). A number of studies have also found a positive correlation between Roseobacter abundance with either chl a (González et al. 2000) or nutrient concentrations (Brown et al. 2005), and similar conclusions have been achieved based on the seasonal abundance of this group in the Mediterranean Sea (Alonso-Sáez et al. 2007). Our findings provide further support of a possible preference of Roseobacter for environmental settings leading to high primary production.

Members of the SAR11 clade constituted the large majority of Alphaproteobacteria cells, and were highly abundant at all stations, dominating the bacterial community throughout the Río de la Plata estuary (Fig. 4). Typically, this bacterial group has been identified in several marine coastal and open-ocean waters, where it frequently contributes to a high extent to the total bacterial abundance (Morris et al. 2002, Alonso \& Pernthaler 2006, Vila-Costa et al. 2007). Furthermore, high numbers of SAR11 cells have also been reported in estuaries (Hewson \& Fuhrman 2004, Kirchman et al. 2005). In the present study, the only factor apparently influencing the abundance of SAR11 cells was the geographical distance between samples (Fig. S2).

\section{Geographic influence on bacterial diversity patterns}

As previously mentioned (see 'Environmental structuring of bacterioplankton communities'), geography did have an influence on bacterial diversity at the level of species/strains (Table 1). Moreover, the analysis of $16 \mathrm{~S}$ rRNA gene sequences revealed the existence of 
single sequences, or sequence clusters of $99 \%$ identity within several bacterial groups (i.e. Flavobacteria, Actinobacteria, SAR11, NOR5, SAR86) which were exclusively recovered from one of the different regions of the gradient. These results, though exciting, are not surprising, as our sampling scale $(\sim 150 \mathrm{~km})$ is within the frame identified by Martiny et al. (2006) as suitable for detecting both environmental and geographical influence on microbial diversity. Certainly, these findings deserve a specific experimental approach to corroborate or discard a potential geographically based differentiation among the bacterial inhabitants of this system.

\section{Which portion of the gradient is more diverse?}

Diversity patterns derived from ARISA data showed the highest richness and number of unique OTUs at the frontal zone, indicating that this region may contain the highest diversity in this system (Fig. 3A). The relatively high number of unique OTUs in the frontal zone subset suggests the existence of a particular bacterial assemblage in this area. In addition, most of the OTUs retrieved from this zone were in fact common to the riverine and/or marine stations, suggesting that a substantial portion of the riverine and marine microorganisms would be able to thrive in the frontal zone as well. Alternatively, this finding could also result from a mere mixing of the bacterial assemblages, without implying a real ability of the corresponding bacteria to live and grow at the frontal zone. Thus, activity measurements linked to bacterial identification are needed to clarify the extent to which the riverine and marine microbial populations are active and growing at the mixing front.

Previous studies in comparable systems have also found that the communities of the transitional regions of the gradient often include members of the extremes, besides a characteristic brackish assemblage (Selje \& Simon 2003, Crump et al. 2004, Riemann et al. 2008). However, there is currently no agreement on whether the bacterial communities at the transitional portions of these gradients are more or less diverse than their purely freshwater and marine counterparts. Contradictory conclusions have been obtained (Hollibaugh et al. 2000, Troussellier et al. 2002, Hewson \& Fuhrman 2004), even for the same system in different seasons (Crump et al. 2004). Though the stability of any pattern found for a given system certainly needs to be confirmed with several sampling campaigns, our data strongly support the idea that the highest bacterial diversities are found at the frontal zone of estuaries.

The different areas of the estuary also differed in the number of total bacterial cells (Fig. 4). Decline in the bacterial abundance from the riverine towards the marine portions have been repeatedly observed for similar environments (Troussellier et al. 2002, Kirchman et al. 2003, Zhang et al. 2006). Interestingly, the highest bacterial abundance in our system was found in the frontal zone, in co-occurrence with the highest concentrations of organic matter and chl $a$, suggesting that this portion of the gradient would not only be the most diverse, but also the most productive from the bacterial point of view. Further work is needed to evaluate this hypothesis, and to establish the contribution of the different bacterial groups here identified in the generation of microbial biomass in this system.

Acknowledgements. We thank P. Castro and A. Segura for assistance during the sampling campaign. G. Pérez is acknowledged for valuable help during nutrient analysis. The crew and accompanying scientific staff from RV 'Aldebaran' are acknowledged for providing an excellent working atmosphere. The authors also thank 3 anonymous reviewers, whose insightful comments led to a substantial improvement of a previous version of this manuscript. B. de Valizas is also acknowledged for providing an inspiring atmosphere for the final synthesis of this work. This study was funded by the Max Planck Society; the sampling campaign was supported by DINARA.

\section{LITERATURE CITED}

Abell GCJ, Bowman JP (2005a) Colonization and community dynamics of class Flavobacteria on diatom detritus in experimental mesocosms based on Southern Ocean seawater. FEMS Microbiol Ecol 53:379-391

Abell GCJ, Bowman JP (2005b) Ecological and biogeographic relationships of class Flavobacteria in the Southern Ocean. FEMS Microbiol Ecol 51:265-277

Acha EM, Mianzan H, Guerrero R, Carreto J, Giberto D, Montoya N, Carignan M (2008) An overview of physical and ecological processes in the Rio de la Plata Estuary. Cont Shelf Res 28:1579-1588

Alonso C, Pernthaler J (2006) Roseobacter and SAR11 dominate microbial glucose uptake in coastal North Sea waters. Environ Microbiol 8:2022-2030

Alonso C, Zeder M, Piccini C, Conde D, Pernthaler J (2009) Ecophysiological differences of betaproteobacterial populations in two hydrochemically distinct compartments of a subtropical lagoon. Environ Microbiol 11:867-876

Alonso-Saez L, Gasol JM (2007) Seasonal variations in the contributions of different bacterial groups to the uptake of low-molecular-weight compounds in northwestern Mediterranean coastal waters. Appl Environ Microbiol 73: 3528-3535

Alonso-Sáez L, Balagué V, Sà EL, Sánchez O and others (2007) Seasonality in bacterial diversity in north-west Mediterranean coastal waters: assessment through clone libraries, fingerprinting and FISH. FEMS Microbiol Ecol 60:98-112

Anton J, Rossello-Mora R, Rodriguez-Valera F, Amann R (2000) Extremely halophilic bacteria in crystallizer ponds from solar salterns. Appl Environ Microbiol 66:3052-3057

Ashelford KE, Chuzhanova NA, Fry JC, Jones AJ, Weightman AJ (2006) New screening software shows that most recent 
large 16S rRNA gene clone libraries contain chimeras. Appl Environ Microbiol 72:5734-5741

Barberán A, Casamayor EO (2010) Global phylogenetic community structure and $\beta$-diversity patterns in surface bacterioplankton metacommunities. Aquat Microb Ecol 59:1-10

Bianchi AA, Bianucci L, Piola AR, Ruiz Pino D, Schloss I, Poisson A, Balestrini CF (2005) Vertical stratification and airsea $\mathrm{CO}_{2}$ fluxes in the Patagonian shelf. J Geophys Res 110:C07003 doi: 10.1029/2004JC002488

Bisbal GA (1995) The Southeast South American shelf large marine ecosystem: evolution and components. Mar Policy 19:21-38

Boltovskoy D, Gibbons MJ, Hutchings L, Biinet D (1990) General biological features of South Atlantic. In: Boltovskoy D (ed) Zooplankton. Backhyus Publishers, Leiden, p 1-42

$>$ Bouvier TC, del Giorgio PA (2002) Compositional changes in free-living bacterial communities along a salinity gradient in two temperate estuaries. Limnol Oceanogr 47: 453-470

Brown MV, Schwalbach MS, Hewson I, Fuhrman JA (2005) Coupling 16S-ITS rDNA clone libraries and automated ribosomal intergenic spacer analysis to show marine microbial diversity: development and application to a time series. Environ Microbiol 7:1466-1479

$>$ Calliari D, Brugnoli E, Ferrari G, Vizziano D (2009) Phytoplankton distribution and production along a wide environmental gradient in the South-West Atlantic off Uruguay. Hydrobiologia 620:47-61

Cardinale M, Brusetti L, Quatrini P, Borin S and others (2004) Comparison of different primer sets for use in automated ribosomal intergenic spacer analysis of complex bacterial communities. Appl Environ Microbiol 70:6147-6156

Carreto JI, Montoya NG, Benavides HR, Guerrero R, Carignan MO (2003) Characterization of spring phytoplankton communities in the Río de La Plata maritime front using pigment signatures and cell microscopy. Mar Biol 143: 1013-1027

Clarke KR, Gorley RN (2006) PRIMER v6: user manual/tutorial. PRIMER-E, Plymouth

> Clarke KR, Somerfield PJ, Gorley RN (2008) Testing of null hypotheses in exploratory community analyses: similarity profiles and biota-environment linkage. J Exp Mar Biol Ecol 366:56-69

Cottrell MT, Kirchman DL (2003) Contribution of major bacterial groups to bacterial biomass production (thymidine and leucine incorporation) in the Delaware estuary. Limnol Oceanogr 48:168-178

$>$ Crump BC, Armbrust EV, Baross JA (1999) Phylogenetic analysis of particle-attached and free-living bacterial communities in the Columbia River, its estuary, and the adjacent coastal ocean. Appl Environ Microbiol 65:3192-3204

Crump BC, Hopkinson CS, Sogin ML, Hobbie JE (2004) Microbial biogeography along an estuarine salinity gradient: combined influences of bacterial growth and residence time. Appl Environ Microbiol 70:1494-1505

Daims H, Bruhl A, Amann R, Schleifer KH, Wagner M (1999) The domain-specific probe EUB338 is insufficient for the detection of all Bacteria: development and evaluation of a more comprehensive probe set. Syst Appl Microbiol 22: 434-444

DeLong EF, Franks DG, Alldredge AL (1993) Phylogenetic diversity of aggregate-attached vs. free-living marine bacterial assemblages. Limnol Oceanogr 38:924-934

Eaton AD, Clesceri LS, Rice EW, Greenberg AE, Franson MAH (eds) (2005) Standard methods for the examination of water and wastewater: centennial edition. American Public Health Association, Washington, DC
Eilers H, Pernthaler J, Glöckner FO, Amann R (2000) Culturability and in situ abundance of pelagic bacteria from the North Sea. Appl Environ Microbiol 66:3044-3051

> Eilers H, Pernthaler J, Peplies J, Glöckner FO, Gerdts G, Amann R (2001) Isolation of novel pelagic bacteria from the German Bight and their seasonal contribution to surface picoplankton. Appl Environ Microbiol 67:5134-5142

Fandino LB, Riemann L, Steward GF, Azam F (2005) Population dynamics of Cytophaga-Flavobacteria during marine phytoplankton blooms analyzed by real-time quantitative PCR. Aquat Microb Ecol 40:251-257

Feely RA, Sabine CL, Takahashi T, Wanninkhof R (2001) Uptake and storage of carbon dioxide in the ocean: the global $\mathrm{CO}_{2}$ survey. Oceanography (Wash DC) 14:18-32

- Framiñan MB, Brown OB (1996) Study of the Río de la Plata turbidity front, Part I: spatial and temporal distribution. Cont Shelf Res 16:1259-1282

> Frank JA, Reich CI, Sharma S, Weisbaum JS, Wilson BA, Olsen GJ (2008) Critical evaluation of two primers commonly used for amplification of bacterial 16S rRNA genes. Appl Environ Microbiol 74:2461-2470

> Glöckner FO, Fuchs BM, Amann R (1999) Bacterioplankton compositions of lakes and oceans: a first comparison based on fluorescence in situ hybridization. Appl Environ Microbiol 65:3721-3726

Gomez-Pereira PR, Fuchs BM, Alonso C, Oliver M, van Beusekom J, Amann R (2010) Distinct flavobacterial communities in contrasting water masses of the North Atlantic Ocean. ISME J 4:472-487

González JM, Simo R, Massana R, Covert JS, Casamayor EO, Pedros-Alio C, Moran MA (2000) Bacterial community structure associated with a dimethylsulfoniopropionateproducing North Atlantic algal bloom. Appl Environ Microbiol 66:4237-4246

Grossart HP, Levold F, Allgaier M, Simon M, Brinkhoff T (2005) Marine diatom species harbour distinct bacterial communities. Environ Microbiol 7:860-873

Guerrero RA, Acha EM, Framiñan MB, Lasta CA (1997) Physical oceanography of the Río de la Plata estuary, Argentina. Cont Shelf Res 17:727-742

> Hahn MW, Pöckl M, Wu QL (2005) Low intraspecific diversity in a Polynucleobacter subcluster population numerically dominating bacterioplankton of a freshwater pond. Appl Environ Microbiol 71:4539-4547

> Hewson I, Fuhrman JA (2004) Richness and diversity of bacterioplankton species along an estuarine gradient in Moreton Bay, Australia. Appl Environ Microbiol 70: 3425-3433

> Hollibaugh JT, Wong PS, Murrell MC (2000) Similarity of particle-associated and free-living bacterial communities in northern San Francisco Bay, California. Aquat Microb Ecol 21:103-114

Jeffrey SW, Humphrey GF (1975) New spectrophotometric equations for determining chlorophylls $\mathrm{a}, \mathrm{b}, \mathrm{c} 1$ and $\mathrm{c} 2$ in higher plants, algae and natural phytoplankton. Biochem Physiol Pflanz 167:191-194

Kirchman DL, Yu LY, Cottrell MT (2003) Diversity and abundance of uncultured Cytophaga-like bacteria in the Delaware Estuary. Appl Environ Microbiol 69:6587-6596

Kirchman DL, Dittel AI, Malmstrom RR, Cottrell MT (2005) Biogeography of major bacterial groups in the Delaware estuary. Limnol Oceanogr 50:1697-1706

Koroleff F (1976) Determination of ammonia. In: Grasshoft $\mathrm{K}$ (ed) Methods of seawater analysis. Verlag Chemie, New York, NY p 126-133

Legendre P, Gallagher ED (2001) Ecologically meaningful transformations for ordination of species data. Oecologia 129:271-280 
Legendre P, Legendre L (1998) Numerical ecology, 2nd English edn. Elsevier Science, Amsterdam

> Lorenzen CJ (1967) Determination of chlorophyll and pheopigments: spectrophotometric equations. Limnol Oceanogr 12:343-346

Lozupone CA, Knight R (2007) Global patterns in bacterial diversity. Proc Natl Acad Sci USA 104:11436-11440

Ludwig W, Strunk O, Westram R, Richter L and others (2004) ARB: a software environment for sequence data. Nucleic Acids Res 32:1363-1371

Malmstrom RR, Straza TRA, Cottrell MT, Kirchman DL (2007) Diversity, abundance, and biomass production of bacterial groups in the western Arctic Ocean. Aquat Microb Ecol 47:45-55

Manz W, Amann R, Ludwig W, Wagner M, Schleifer KH (1992) Phylogenetic oligodeoxynucleotide probes for the major subclasses of Proteobacteria: problems and solutions. Syst Appl Microbiol 15:593-600

Manz W, Amann R, Ludwig W, Vancanneyt M, Schleifer KH (1996) Application of a suite of 16S rRNA-specific oligonucleotide probes designed to investigate bacteria of the phylum Cytophaga-Flavobacter-Bacteroides in the natural environment. Microbiology 142:1097-1106

Martinez CM, Retta S (2001) Caracterizacion de las areas de cria de la corvina (Micropogonias furnieri) en la zona costera uruguaya. In: Vizziano D, Puig P, Mesones C, Nagy G (eds) El Rio de la Plata. Investigacion para la gestion del Ambiente, los recursos pesqueros y la pesqueria en el frente salino. Programa Ecoplata, Montevideo, p 141-148

Martiny JBH, Bohannan BJM, Brown JH, Colwell RK and others (2006) Microbial biogeography: putting microorganisms on the map. Nat Rev Microbiol 4:102-112

Moran MA, González JM, Kiene RP (2003) Linking a bacterial taxon to sulfur cycling in the sea: studies of the marine Roseobacter group. Geomicrobiol J 20:375-388

> Morris RM, Rappe MS, Connon SA, Vergin KL, Siebold WA, Carlson CA, Giovannoni SJ (2002) SAR11 clade dominates ocean surface bacterioplankton communities. Nature 420: 806-810

Murphy J, Riley JP (1962) A modified single solution method for the determination of phosphate in natural waters. Anal Chim Acta 27:31-36

Murray AE, Hollibaugh JT, Orrego C (1996) Phylogenetic compositions of bacterioplankton from two California estuaries compared by denaturing gradient gel electrophoresis of 16S rDNA fragments. Appl Environ Microbiol 62:2676-2680

Muyzer G, Teske A, Wirsen CO, Jannasch HW (1995) Phylogenetic relationship of Thiomicrospira species and their identification in deep-sea hydrothermal vent samples by denaturing gradient gel electrophoresis of $16 \mathrm{~S}$ rDNA fragments. Arch Microbiol 164:165-172

Nagy G, Gómez M, López C, Perdomo A (2002) Distribution patterns of nutrients and symptoms of eutrophication in the Río de la Plata Estuary System. Hydrobiologia 475476:125-139

Neef A (1997) Anwendung der in situ-Einzelzell-Identifizierung von Bakterien zur Populationsanalyse in komplexen mikrobiellen Biozönosen. PhD thesis, Technical University Munich

> Neef A, Amann R, Schlesner H, Schleifer KH (1998) Monitoring a widespread bacterial group: in situ detection of planctomycetes with 16S rRNA-targeted probes. Microbiology 144:3257-3266

O'Sullivan LA, Fuller KE, Thomas EM, Turley CM, Fry JC, Weightman AJ (2004) Distribution and culturability of the uncultivated 'AGG58 cluster' of Bacteroidetes phylum in aquatic environments. FEMS Microbiol Ecol 47:359-370

Pernthaler A, Pernthaler J, Amann R (2002) Fluorescence in situ hybridization and catalyzed reporter deposition for the identification of marine bacteria. Appl Environ Microbiol 68:3094-3101

> Piccini C, Conde D, Alonso C, Sommaruga R, Pernthaler J (2006) Blooms of single bacterial species in a coastal lagoon of the Southwestern Atlantic Ocean. Appl Environ Microbiol 72:6560-6568

Pinhassi J, Berman T (2003) Differential growth response of colony-forming alpha- and gamma-proteobacteria in dilution culture and nutrient addition experiments from Lake Kinneret (Israel), the eastern Mediterranean Sea, and the Gulf of Eilat. Appl Environ Microbiol 69:199-211

Pinhassi J, Sala MM, Havskum H, Peters F, Guadayol O, Malits A, Marrase CL (2004) Changes in bacterioplankton composition under different phytoplankton regimens. Appl Environ Microbiol 70:6753-6766

> Pommier T, Canbäck B, Riemann L, Boström KH, Simu K, Lundberg P, Tunlid A, Hagström Å (2007) Global patterns of diversity and community structure in marine bacterioplankton. Mol Ecol 16:867-880

Pruesse E, Quast C, Knittel K, Fuchs BM, Ludwig W, Peplies J, Glockner FO (2007) SILVA: a comprehensive online resource for quality checked and aligned ribosomal RNA sequence data compatible with ARB. Nucleic Acids Res 35:7188-7196

> Ramette A (2007) Multivariate analyses in microbial ecology. FEMS Microbiol Ecol 62:142-160

Ramette A (2009) Quantitative community fingerprinting methods for estimating the abundance of operational taxonomic units in natural microbial communities. Appl Environ Microbiol 75:2495-2505

Riemann L, Steward GF, Azam F (2000) Dynamics of bacterial community composition and activity during a mesocosm diatom bloom. Appl Environ Microbiol 66:578-587

Riemann L, Leitet C, Pommier T, Simu K, Holmfeldt K, Larsson U, Hagstrom A (2008) The native bacterioplankton community in the central Baltic Sea is influenced by freshwater bacterial species. Appl Environ Microbiol 74: 503-515

> Roller C, Wagner M, Amann R, Ludwig W, Schleifer KH (1994) In situ probing of Gram-positive bacteria with high DNA G+C content using 23S rRNA-targeted oligonucleotides. Microbiology 140:2849-2858

Schattenhofer M, Fuchs BM, Amann R, Zubkov MV, Tarran GA, Pernthaler J (2009) Latitudinal distribution of prokaryotic picoplankton populations in the Atlantic Ocean. Environ Microbiol 11:2078-2093

Selje N, Simon M (2003) Composition and dynamics of particle-associated and free-living bacterial communities in the Weser estuary, Germany. Aquat Microb Ecol 30: 221-237

Simek K, Pernthaler J, Weinbauer M, Hornak K and others (2001) Changes in bacterial community composition, dynamics and viral mortality rates associated with enhanced flagellate grazing in a mesoeutrophic reservoir. Appl Environ Microbiol 67:2723-2733

Simon M, Glöckner FO, Amann R (1999) Different community structure and temperature optima of heterotrophic picoplankton in various regions of the Southern Ocean. Aquat Microb Ecol 18:275-284

> Simonato F, Gómez-Pereira PR, Fuchs BM, Amann R (2010) Bacterioplankton diversity and community composition in the Southern Lagoon of Venice. Syst Appl Microbiol 33: $128-138$ 
Stamatakis A (2006) RAxML-VI-HPC: maximum likelihoodbased phylogenetic analyses with thousands of taxa and mixed models. Bioinformatics 22:2688-2690

Strickland JDH, Parsons TR (1972) A practical handbook of sea water analysis. Fish Res Board Can Bull 167:207-211

Troussellier M, Schafer H, Batailler N, Bernard L and others (2002) Bacterial activity and genetic richness along an estuarine gradient (Rhone River plume, France). Aquat Microb Ecol 28:13-24

Valderrama JC (1981) The simultaneous analysis of total nitrogen and total phosphorus in natural waters. Mar Chem 10:109-122

Vila-Costa M, Pinhassi J, Alonso C, Pernthaler J, Simo R (2007) An annual cycle of dimethylsulfoniopropionate-sulfur and leucine assimilating bacterioplankton in the coastal NW Mediterranean. Environ Microbiol 9: 2451-2463

Warnecke F, Sommaruga R, Hofer JS, Pernthaler J (2005) Abundances, identity and growth state of Actinobacteria

Editorial responsibility: Jed Fuhrman,

Los Angeles, California, USA in mountain lakes of different transparency. Appl Environ Microbiol 71:5551-5559

Watanabe K, Watanabe K, Kodama Y, Syutsubo K, Harayama S (2000) Molecular characterization of bacterial populations in petroleum-contaminated groundwater discharged from underground crude oil storage cavities. Appl Environ Microbiol 66:4803-4809

Woebken D, Fuchs BM, Kuypers MMM, Amann R (2007) Potential interactions of particle-associated anammox bacteria with bacterial and archaeal partners in the Namibian upwelling system. Appl Environ Microbiol 73:4648-4657

- Zhang Y, Jiao N, Cottrell MT, Kirchman DL (2006) Contribution of major bacterial groups to bacterial biomass production along a salinity gradient in the South China Sea. Aquat Microb Ecol 43:233-241

$>$ Zhou J, Bruns MA, Tiedje JM (1996) DNA recovery from soils of diverse composition. Appl Environ Microbiol 62: 316-322

Submitted: November 30, 2009; Accepted: July 12, 2010 Proofs received from author(s): August 26, 2010 